\title{
Seed production and soil seed bank in three evergreen woody species from a neotropical savanna
}

\author{
CARLOS GARCÍA-NÚÑEZ1, AURA AZÓCAR and JUAN F. SILVA \\ Instituto de Ciencias Ambientales y Ecológicas, Facultad de Ciencias, Universidad de Los \\ Andes, Mérida 5101, Venezuela
}

(Accepted 8th December 2000)

\begin{abstract}
Results of a 3-y study on the populations of three evergreen woody species (Byrsonima crassifolia, Palicourea rigida and Bowdichia virgilioides), from a regularly burnt savanna, in Venezuela, are reported. Tree density, size structure, fruitseed production per tree of different size classes and soil seed bank were estimated. Viable seed production was one order of magnitude higher in B. crassifolia, which was also the only species with a permanent soil seed bank. Seeds of $B$. virgilioides germinated readily after dispersal, whilst seeds of $P$. rigida showed an innate dormancy synchronously released after a year. Both of the latter species seemed to maximize the first growth season by germinating at the beginning of the favourable season. In B. crassifolia, germination proceeds with an early small burst of germination, possibly followed by a second peak at the beginning of the next rainy season and little or no germination thereafter. The results showed that despite the high fire frequency, the studied species produce a substantial number of viable propagules, and have the capacity to germinate in field conditions (readiness depending on the species). Sexual reproduction is expected, therefore, to play an important role, as suggested by their reproductive investment, in longterm population maintenance.
\end{abstract}

KEY WORDS: fire, fruit production, germination, population persistence, reproductive strategies, resprout, savanna trees, seed dispersal

\section{INTRODUCTION}

The neotropical savannas are characterized by the coexistence of two contrasting life forms, grasses and trees. This ecosystem is homogeneously dystrophic, strongly seasonal, as a consequence of the concentration of rains, and subjected to fires almost every dry season (Sarmiento 1984). Under these conditions, species of evergreen sclerophyllous trees persist forming a variably sparse

\footnotetext{
${ }^{1}$ Corresponding author. Email: cgarcia@ciens.ula.ve
} 
woody layer in which density determines the types of physiognomy. Tree density seems to be determined by two main factors: plant available moisture throughout the year and fire (Medina \& Silva 1990, Solbrig et al. 1996).

The high fire frequency prevailing in savanna ecosystems, and a prolonged dry season, can be considered the major limitations for sexual reproduction in savanna woody species, due to their negative effects on seeds and seedlings (Bradstock \& Myerscough 1988, Ferri 1961; Hoffmann 1996, 1998; Rizzini \& Heringer 1962). These authors considered that under these conditions, vegetative reproduction could be more successful than sexual reproduction. Although there is little information on seedling establishment in tropical savannas, some studies have shown the functionality of sexual reproduction in woody species. In the Brazilian cerrado, Labouriau et al. (1964) found several tree species germinating under natural conditions, and also found young plants originated from seeds. More recently, Oliveira \& Silva (1993), working with two species of Kielmeyera, found fast germination after the beginning of the wet season, early root swelling forming a xylopodium which enables high survivorship during the dry season, and recurring sprouting from the swollen root system following fire during the first years of development.

Since most species bloom during the dry season, losses of reproductive material due to fire are important. Hoffmann (1998), working on post-burn reproduction in some woody plants of the Brazilian cerrado, showed that fire caused an immediate reduction in sexual reproduction success by destroying reproductive structures and seeds. He found an overall reduction in seed production after fire in five of the six studied species. Nevertheless, the negative effects of fire on sexual reproduction, depend not only on spatial and temporal variations of fire, but also on specific traits such as natural life-size, architecture, phenology, size-dependent reproductive output, mechanisms to protect seeds from burning, and ability of seedlings to resprout.

Although short-term population maintenance in woody species is assured by their sprouting ability, understanding the different steps of the reproduction processes is necessary to assess long-term tree dynamics in tropical savannas. Little is known, however, about the reproductive capacity and the fate of the propagules, and how different reproductive syndromes are represented in species of the same functional group.

In this study, we examine some reproductive aspects of three widely distributed savanna woody species in order to evaluate their potential sexual reproductive capacity under a high fire frequency regime. First, we examine tree density, size structure of the population and fruit-seed production per tree of different size classes to quantify propagule input per unit area. Second, we quantify the soil seed bank and its dynamics to determine the contribution of soil stored seeds to the regeneration of the population. Third, we examine the viability and germination of seeds under laboratory conditions to find the proportion of viable propagules produced per tree and the germination requirements. 


\section{STUDY SITE AND SPECIES}

The study area is a typical seasonal savanna located on the Andean piedmont hills of Barinas State $\left(8^{\circ} 38^{\prime} \mathrm{N}-70^{\circ} 12^{\prime} \mathrm{W}\right)$. The mean annual temperature is $27^{\circ} \mathrm{C}$, and the mean annual rainfall is $1500 \mathrm{~mm}$. Temperature varies little throughout the year, but rainfall is markedly seasonal, with 4-5 mo with little or no rain (December to April) and a wet season from April to November. The abundance of woody elements, a very extensive human use and the occurrence of fires, almost every year, characterize these savannas (Silva \& Sarmiento 1976). The dominant woody species are Byrsonima crassifolia, Curatella americana, Palicourea rigida, Bowdichia virgilioides and Casearia sylvestris. Dominant in the grass layer are Trachypogon plumosus, Sporobolus cubensis, Leptocoryphium lanatum, Elyonurus adustus and Andropogon semiberbis. Four contiguous $2500-\mathrm{m}^{2}$ plots were delimited in this area. Each plot was further subdivided into eight 25-m $\times$ $12.5-\mathrm{m}$ subplots to carry out the sampling described below. These plots were burned every year during the study period during the dry season.

The three dominant evergreen tree species in the study area which grow predominantly as isolated individuals in the grassland were selected. They present similarities in their general ecology but differ in fruit morphology and dispersal. These species are: Bowdichia virgilioides H.B.K (Leguminosae), the tallest evergreen tree in these savannas, usually between 4 to $10 \mathrm{~m}$ in height, with a legume fruit $4-7.5 \mathrm{~cm}$ long, 10-15 mm wide, flat, very light $(0.08-0.11$ $\mathrm{g})$ and wind dispersed. Seed size is 5 to $6 \mathrm{~mm}$ and average weight is $0.02 \mathrm{~g}$. Byrsonima crassifolia (L.) Rich. (Malpighiaceae), a small tree, usually 4-6 m in height, with drupaceous fruits, which present a yellow colour when ripe, characterized by a very hard inner coat, $5-8 \mathrm{~mm}$ in diameter, $0.47-0.51 \mathrm{~g}$ in weight and bird dispersed (D. Wütherich, unpubl. data). The seeds are small, 2.6$3.0 \mathrm{~mm}$, soft and very light $(0.00290-0.00298 \mathrm{~g})$. Inflorescences form terminal racemes. This species is self-compatible but is more successful when crosspollinated (Bawa 1974). Palicourea rigida H.B.K (Rubiaceae), an even smaller tree, usually does not reach over $3 \mathrm{~m}$ in height. It is a heterostylous species with black berry fruits, $5 \mathrm{~mm}$ long, 0.3-0.4 $\mathrm{g}$ in weight and bird dispersed (Wütherich et al. in press). Seeds are characterized by a hard seed coat. Seed size range and average weight are $4-5 \mathrm{~mm}$ and $0.02 \mathrm{~g}$ respectively.

The study was carried out during the period 1993-95, but most of the sampling on reproductive parameters was conducted in 1994. Field data allowed us to determine tree density, flower and fruit output, phenological characteristics and size structure of each population. For each individual plant, total height and stem girth at the base were measured. The plots were visited monthly and the phenological condition of individuals in each population was recorded. An additional sampling to determine seedling density in P. rigida, was performed in 10 locations (plots of $3-\mathrm{m} \times 3-\mathrm{m}$ ) around adult parent trees, in a $2500-\mathrm{m}^{2}$ subplot. 
METHODS

\section{Reproductive parameters}

To count flowers and fruits and to estimate the rate of flower to fruit yield, 15 to 20 inflorescences and 15 to 20 fruits from individual trees in each population were collected (for sample sizes, see Table 1). Data from P. rigida were collected in 1993, 1994 and 1995 and for B. crassifolia in 1994 and 1995. To determine fruit and seed production per plant in P. rigida and B. crassifolia, 15 flowering trees were labelled within the whole size range in each population during the 1993, 1994 and 1995 dry season in the former and in 1994 and 1995 for the latter. Since $P$. rigida fruits ripen slowly and progressively, we enclosed each fruit in mesh cloth and collected the ripe fruits at each visit. All fruits were harvested and counted in small B. crassifolia trees. In large trees, a first order branch was randomly selected, and the second and third order branches and their fruits counted. Then, we estimated the number of equivalent branches and extrapolated to the whole tree. A sample of fruits was randomly collected from each of 10 labelled trees of all species and taken to the laboratory for further examination. The seeds were classified as intact or damaged (empty). Viable seeds per fruit were determined by viability tests using $0.03 \%$ tetrazolium chloride (Moore 1973). Seed production was calculated by multiplying the estimated number of fruits per tree by the mean number of intact seeds per fruit.

Table 1. Mean values $\pm \mathrm{SE}$ of flower, fruit and seed production in the three studied species in a seasonal savanna in Barinas, Venezuela ( $\mathrm{n}$ is shown in parentheses).

\begin{tabular}{lccc}
\hline Parameters & Byrsonima crassifolia & Palicourea rigida & Bowdichia virgilioides \\
\hline Flowers/inflorescence & $33.97 \pm 3.82(15)$ & $249.41 \pm 22.32(15)$ & $90.27 \pm 9.52(10)$ \\
Fruits/infructescence & $22.17 \pm 1.54(15)$ & $80.46 \pm 20.0(20)$ & $8.67 \pm 1.07(10)$ \\
\% flower abortion & 34.74 & 63.83 & 90.39 \\
Fruits/individual & $27946 \pm 6223(15)$ & $1197 \pm 392(15)$ & $2336 \pm 391(10)$ \\
Seeds/fruit & $2.87 \pm 0.03(110)$ & $2.00 \pm 0.00(100)$ & $2.63 \pm 0.16(76)$ \\
Seeds/individual & 85497 & 3647 & 3799 \\
$\%$ empty seeds & $10.09 \pm 2.16$ & $18.05 \pm 4.24$ & $61.36 \pm 4.45$ \\
$\%$ viable seeds & $56.71 \pm 4.93$ & $81.23 \pm 2.73$ & $48.89 \pm 11.47$ \\
Viable seeds/ind. & 43593 & 2428 & 718 \\
Viable seeds ha & $1.96 \times 10^{-1}$ & $2.79 \times 10^{5}$ & 0.00 \\
\hline
\end{tabular}

Since B. virgiliodes failed to flower during 1994 and 1995, reproductive parameters were determined only in 1993 for 10 labelled trees. The same methods described for $B$. crassifolia were followed. Seed viability and germination tests were performed in 1993 and 1994 using a seed sample collected in 1993.

\section{Soil seed bank}

Soil seed density was estimated from soil samples taken from the surroundings of five individual trees of each of the three species during the dry season of 1994 and 1995. A square wooden frame $(30-\mathrm{cm} \times 30-\mathrm{cm})$ was used to collect three soil samples to a depth of $5 \mathrm{~cm}$, at random intervals, along four radial 
transects $(10 \mathrm{~m}$ in length), orientated towards the cardinal points from each stem $\left(\mathrm{n}=180\right.$ samples; $\left.16.2 \mathrm{~m}^{2}\right)$. In the laboratory, seeds were separated from the soil and litter according to the guidelines recommended by Thompson (1993). Seed viability estimates were made using the tetrazolium test (Moore 1973).

The evaluation of seed bank dynamics by means of buried seeds was only conducted in $B$. crassifolia and $P$. rigida. We enclosed 50 intact seeds of each species in 1-mm mesh nylon bags filled with sieved soil. For each species, 18 bags were randomly buried 2-3 cm deep inside the plot (in July 1994 for $P$. rigida and July 1993 and 1994 for B. crassifolia). Three randomly selected bags of each species were taken out every 2 mo. Recovered seeds were examined and classified as germinated, viable or dead. The criterion for designating germinated seeds was the detection of seedling remains attached to seed coats, or the aperture of one loculus of the drupe in B. crassifolia. The intact seeds were incubated in tetrazolium chloride, and the stained embryos were considered viable.

\section{Seed germination in the laboratory}

Germination experiments were conducted in the laboratory in a growth chamber at $30 \pm 2{ }^{\circ} \mathrm{C}$ and $12 \mathrm{~h}$ light $650 \mu \mathrm{mol} \mathrm{m}{ }^{-2} \mathrm{~s}^{-1} \mathrm{PAR}, 12 \mathrm{~h}$ dark. We used 10 replicates with 25 seeds in each germination test, in a Petri dish with Whatman No. 1 filter paper and distilled water. Fruits were brought from the field in July 1994, and seeds were manually removed and stored under laboratory conditions in sealed plastic containers with silica gel. The experiments were conducted from November 1994 to January 1995. Initially, germination was tested without any previous treatment and in each of the following treatments and control sample was included. Since seeds may be exposed to high temperatures during burning, we tested seed response to several temperatures (Coutinho 1982, González 1967, Silva et al. 1990, Vareschi 1962). We used $70{ }^{\circ} \mathrm{C}-30 \mathrm{~min}, 70{ }^{\circ} \mathrm{C}-60 \mathrm{~min}, 100{ }^{\circ} \mathrm{C}-5 \mathrm{~min}$ and $100{ }^{\circ} \mathrm{C}-30 \mathrm{~min}$ of dry heat and also hot water $\left(92{ }^{\circ} \mathrm{C}\right)$ for 1,5 and 15 min. To scarify seed coats in $P$. rigida, we used concentrated sulphuric acid for 5 to $30 \mathrm{~min}$ and 1 to $4 \mathrm{~h}$ in $B$. crassifolia drupe. Depending on the results we also used combinations of dry heat, wet heat and sulphuric acid. Charred wood from the field was also used as a treatment (Keeley 1987). After each treatment we tested seed viability in a sample of 25 treated seeds. In an additional experiment we cracked drupes of $B$. crassifolia by means of a manual press. Germination was monitored in each experiment during a 90-d period or until all seeds germinated.

RESULTS

\section{Density and size distribution}

Palicourea rigida was the most abundant of the three species (358 plants $\mathrm{ha}^{-1}$ ), followed by B. crassifolia (187 plants ha ${ }^{-1)}$ and B. virgilioides (101 plants ha $\left.{ }^{-1}\right)$. Individuals in each population were classified on the basis of 2-cm classes in basal 
diameter. The distributions of basal diameter (Figure 1) show very similar population size structures in B. crassifolia and $B$. virgilioides, with a high proportion of plants in the lower classes. In $B$. crassifolia, more than half of the population has a basal diameter $\leqslant 4 \mathrm{~cm}$ and in $B$. virgilioides this fraction is even higher $(64 \%)$. In $P$. rigida, the lowest diameter class $(<2 \mathrm{~cm})$ forms only $13 \%$ of the total, whereas the following two classes represent half of the population with a progressive decrease after the second class. Most, if not all plants in the smaller diameter class for all species were evidently resprouts. Actual seedlings were rarely found. However, in the case of $P$. rigida a cohort of germinating seedlings were detected at the beginning of the wet season, mainly surrounding nearby adult trees. A mean seedling density of 2 plants $\mathrm{m}^{-2}$ was found.

Figure 2 combines the allometry of basal diameter vs. total plant height with flowering in 1994-95. Results for B. crassifolia and B. virgilioides are very similar. Height per unit diameter is almost constant below 3 to $4 \mathrm{~m}$ in height (and 10 to $13 \mathrm{~cm}$ in diameter) decreasing markedly thereafter. In P. rigida, the transition occurs at $\leqslant 1 \mathrm{~m}$ tall and $5 \mathrm{~cm}$ in diameter and is less obvious than in the other two species.

\section{Phenology and reproduction}

Byrsonima crassifolia flowered during December and February and set fruit in March. By July the fruits had been completely dispersed. In P. rigida, peak flowering occurred from January to April with inflorescences developing slowly in a basipetal pattern. Fruits were also produced and dispersed in a progressive manner up to July. Even though some $P$. rigida individuals produced flowers later in the rainy season, the fruits from these flowers were generally aborted. Flowering of B. virgilioides in 1993 started in December and continued through January and February, when fruits were set. Fruit dispersal ended in April. Dry season fires typically occur between January and March, when the different species are in the flowering phase.

Data on reproductive parameters are presented in Table 1, corresponding to the sampling conducted in 1994 for $P$. rigida and B. crassifolia, and in 1993 for $B$. virgilioides. Even though the plots burned every year, $B$. crassifolia and $P$. rigida successfully reproduced sexually during the study period, but $B$. virgiliodes flowered only the first year. There were no significant differences in total and in size-specific fruit production for $P$. rigida and $B$. crassifolia between years (Figure 3). There is a wide variation in fruit production relative to the basal diameter of the plant in these two species. The available data on fruit production for $B$. virgiliodes, corresponded only to the intermediate size classes (between 15 and $25 \mathrm{~cm}$ of basal diameter).

Inflorescence arrangement is very different among the three species. Byrsonima crassifolia has the smallest inflorescence, but yields many more inflorescences per plant than the other two species. Flower abortion was also much lower in B. crassifolia than in P. rigida in 1994 (Table 1). As a consequence, fruit production per tree was one order of magnitude higher in B. crassifolia and this 

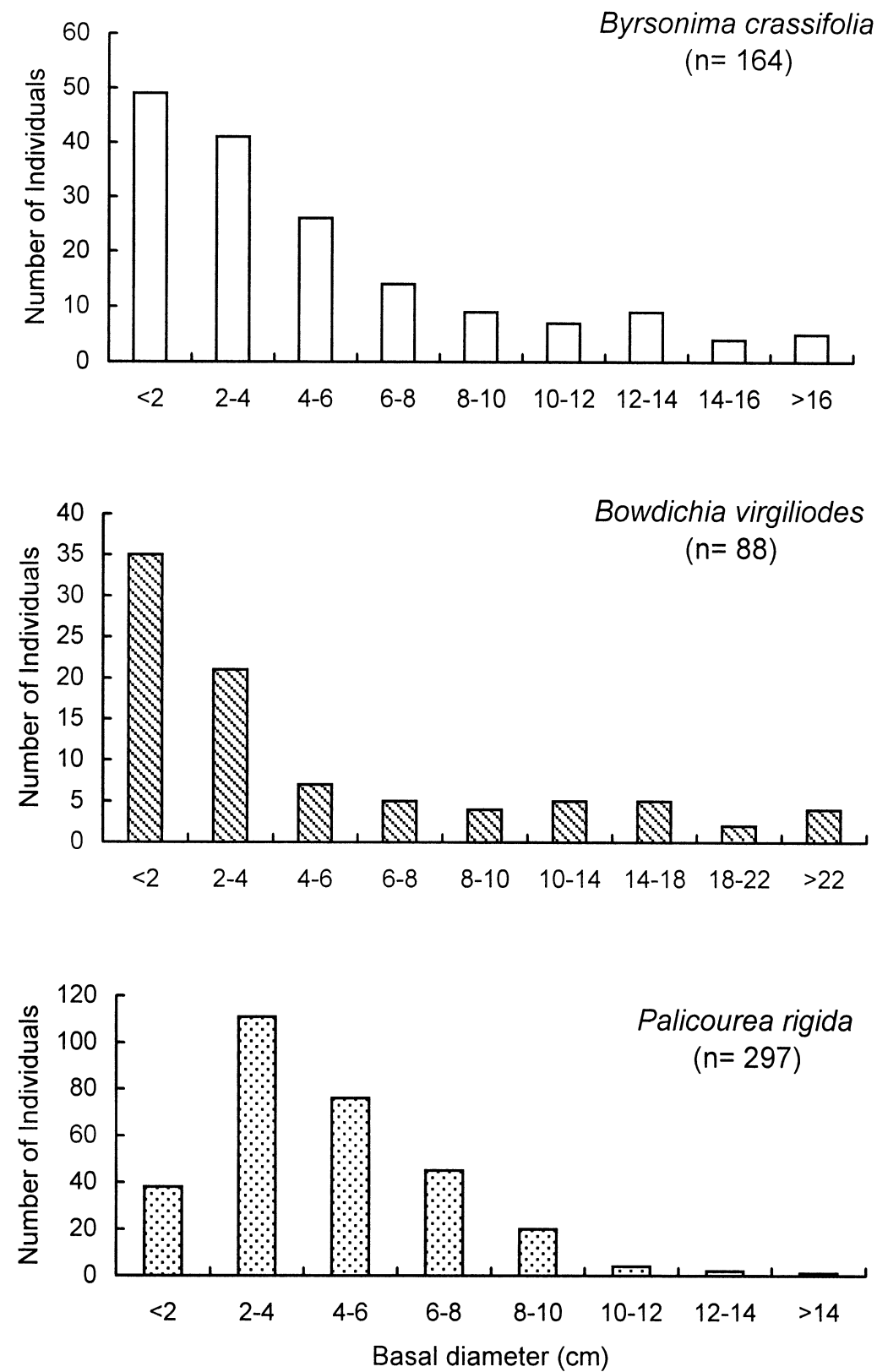

Figure 1. Population structure in classes of basal diameter for the three evergreen woody species studied in a seasonal savanna in Barinas, Venezuela.

species produced more than 20 times more seeds than $P$. rigida in 1994 (Table 1). This also holds when B. crassifolia's 1994 production is compared to B. virgilioides' production. In this last species, more than half the seeds were empty, mostly due to predation, and the number of viable seeds per plant was remarkably low in 1993. 

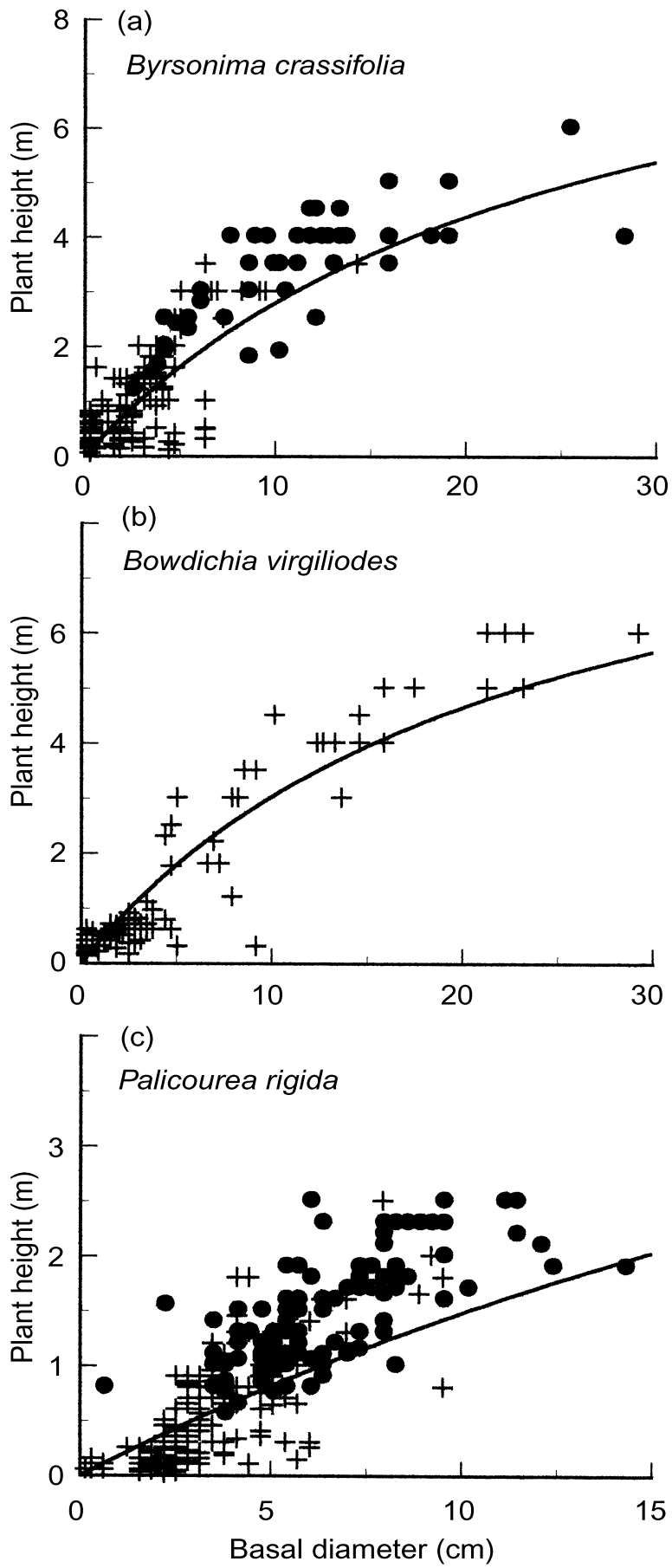

Figure 2. Allometric relationships between height and basal diameter for the three species of woody sclerophyllous trees studied in a seasonal savanna in Barinas, Venezuela. (a) Byrsonima crassifolia, $y=(10 \times x) /$ $(25.66+x), \mathrm{r}^{2}=0.49 ;$ (b) Bowdichia virgiliodes, $y=(10 \times x) /(22.99+x), \mathrm{r}^{2}=0.88 ;$ (c) Palicourea rigida, $y=(8$ $\times x) /(43.94+x), \mathrm{r}^{2}=0.55$. Closed circles: flowering individuals; crosses: non-flowering individuals (in 1994). 
(a)

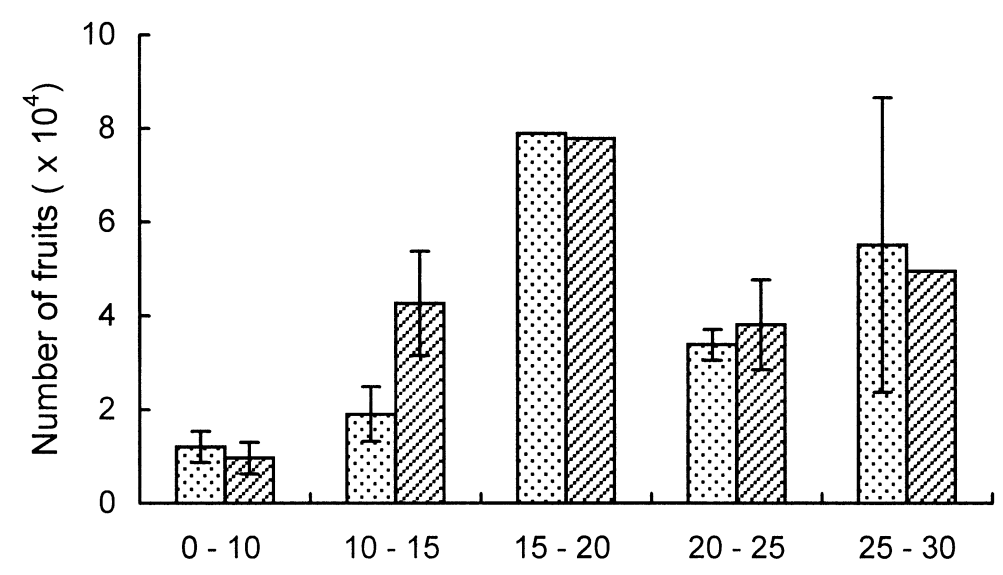

(b)

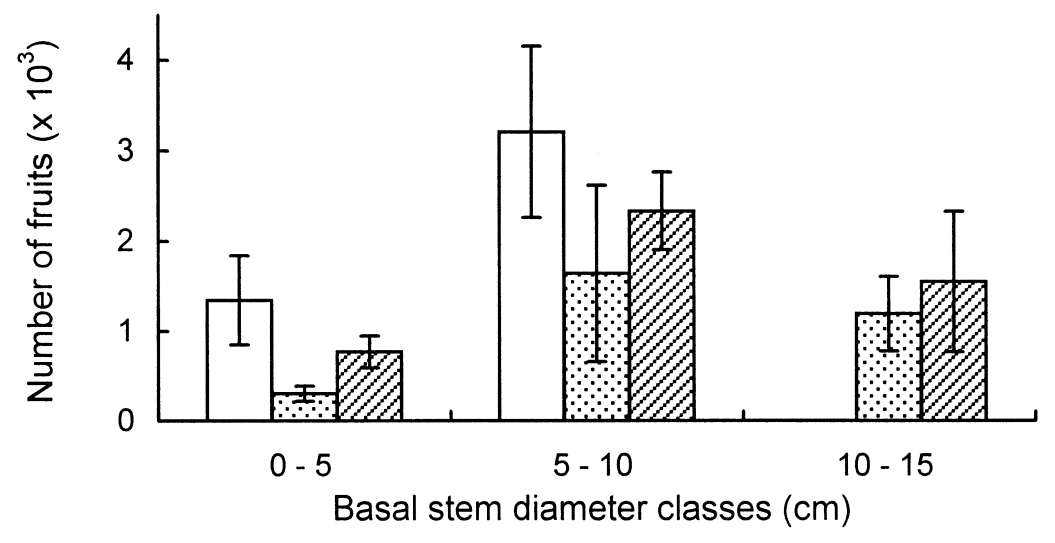

Figure 3. Mean ( \pm SE) fruit crops for different basal stem diameter classes in Byrsonima crassifolia (a) and in Palicourea rigida (b). Open bars: 1993; dotted bars: 1994; striped bars: 1995. Columns without error bars correspond to one individual for that size class.

Seeds in the soil

Total density of seeds per area sampled found in the soil was 38 (2.5 viable seeds $\left.\mathrm{m}^{-2}\right)$ and 54 (3.3 viable seeds $\mathrm{m}^{-2}$ ) viable seeds in 1994 and 1995 respectively, for $B$. crassifolia. In the case of $P$. rigida, we found a total density of 21 (1.3 seeds $\mathrm{m}^{-2}$ ) and $43\left(2.7\right.$ seeds $\left.\mathrm{m}^{-2}\right)$ in 1994 and 1995 respectively, and for B. virgilioides we detected $16\left(1.0\right.$ seeds $\left.\mathrm{m}^{-2}\right)$ seeds in 1994 and none were found in 1995. However, all seeds were dead or empty for both latter species.

As shown in Figure 4, B. crassifolia showed two germination peaks between 1993 and 1994: a small one in November (6\%) and a larger peak in March (17\%) after the beginning of the rains. In the same experiment, between 1994 and 1995, B. crassifolia showed an early small burst of germination, followed by 
(a)

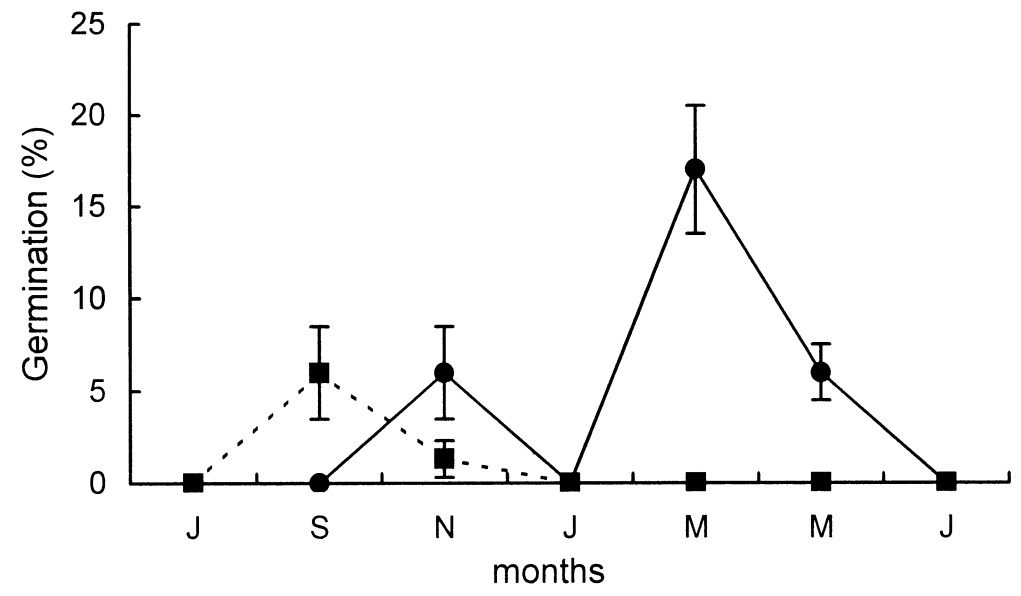

(b)

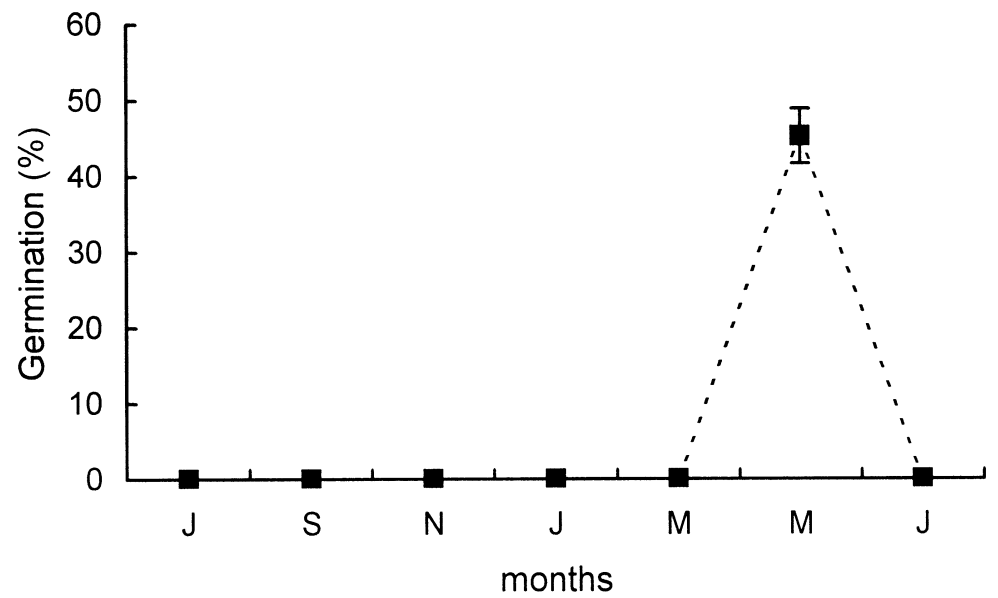

Figure 4. Fraction of germinated seeds which were buried in bags in the soil from July 1993 to July 1994 (-•), and from July 1994 to July 1995 (-) : (a) Byrsonima crassifolia, (b) Palicourea rigida. Values are the means $( \pm \mathrm{SE})$ of three samples.

little or no germination (1 to $6 \%$ ). After a year, only $24 \%$ of the seeds of this species remained viable. In $P$. rigida, half the seeds had died early during the experiment and the other half remained viable without germinating until 10 mo later when all germinated synchronously (Figure 4).

\section{Laboratory germination}

Fifty per cent (all the viable fraction) of B. virgilioides seeds germinated readily without any treatment within the first week, therefore this species was not included in further tests. Palicourea rigida seeds showed no germination in all tests. Viability was not affected by concentrated sulphuric acid nor by $70{ }^{\circ} \mathrm{C}$ 
dry heat but was significantly reduced by more than 1 min wet heat $\left(92{ }^{\circ} \mathrm{C}\right)$ and by $100{ }^{\circ} \mathrm{C}$ dry heat. Byrsonima crassifolia germination was not successful in any of the treatments except for mechanical scarification by cracking which resulted in $40 \%$ germination during the first $3 \mathrm{~d}$ after the treatment. Responses in viability were similar to $P$. rigida.

\section{DISGUSSION}

Our results show that despite the high fire frequency regime prevailing in these savannas, the study species successfully reproduced sexually during the study period. Although flowering phenology is not the same, the three species overlapped their peak of flowering during the dry season. A basal diameter of $4 \mathrm{~cm}$ seems to be a critical threshold for flowering in P. rigida and B. crassifolia, which is equivalent to $\geqslant 1.0 \mathrm{~m}$ in height in both species (Figure 2). Flowering size threshold in $P$. rigida and $B$. crassifolia could be an adaptation to fire. Unfortunately, B. virgilioides did not flower in 1994 and 1995, so data on size at flowering are not available. Birds are likely to be the main dispersal agents in B. crassifolia and P. rigida (D. Wütherich, unpubl. data). In B. virgilioides, fruits are rapidly dispersed by wind, and given their shape and lightness, they are dispersed far away from the tree.

The three species appear very different concerning seeding. Byrsonima crassifolia and $P$. rigida flowered yearly and showed little annual fluctuations in seed crop during the study interval. Byrsonima crassifolia is the more abundant seeder, whereas the other two species showed relatively discrete numbers of seeds. In this species, annual production of fruits varies widely within each size, suggesting the influence of other factors related to site or to genetic variability within the population. Besides the episodic blooming, $B$. virgilioides showed a high degree of failure to set fruit, as has been reported for other populations (Ramirez 1993), a low fraction of viable seeds and a high per cent of seed predation.

Hoffmann (1998) found that fire damage of reproductive structures is an important limiting factor to sexual reproduction for some cerrado woody species. In our study, losses of reproductive structures due to fire must be important, mainly in smaller trees. For example, in B. crassifolia, adult trees that reach a threshold height of up to $3 \mathrm{~m}$, produce a large amount of viable propagules. Palicourea rigida usually flowers after the dry season fires, as happened during this study. However, fire may take place in the wet season, as happened during the 1993 rainy period when it destroyed huge amounts of reproductive material in Palicourea rigida.

The existence of a persistent seed bank in the soil was verified in only one species (B. crassifolia) and it showed no significant changes in a 2-y period. This soil seed bank is very small when compared to those reported for several evergreen shrub species in other open communities (Keeley 1977, Pierce \& 
Cowling 1991, Zammit \& Zedler 1992), which are one to three orders of magnitude greater. Furthermore, the size of the seed bank in B. crassifolia is only $1.2 \%$ of the size of its annual viable seed crop, revealing an important removal of seeds away from the vicinity of the trees. Laminar erosion seems to be an important removal agent, especially in the slopes (C. García-Núñez, pers. obs.). It has been documented (Farji \& Silva 1995) that cutting ants (Atta laevigata) remove huge amounts of fruits from the base of stems in B. crassifolia and transport them, through relatively long distances (around $100 \mathrm{~m}$ ), to their nests. After a variable period of time (several weeks to months), the fruits are taken out from the nests, forming waste piles around it. In this way, seed destruction by fire may be prevented, and at the same time it could provide better conditions for germination.

Notwithstanding the intensity of sampling, the absence of a viable seed bank in the other two species may be due to several causes: the small size of the annual seed crop, $B$. virgilioides' failure to flower during the two years of measurements and its readiness to germinate (see below), fruit removal by wind ( $B$. virgilioides) or by birds ( $P$. rigida), and high temperature damage produced during burning in shallow buried seeds. The results from the buried seeds experiment indicate that $P$. rigida has a transient seed bank which lasts only about a year and is replenished with the current year's seed crop. At the same time, recently germinated seedlings were found in the field under shady conditions at the beginning of the rainy season (May to June). This species seems to form a bank of continuously sprouting plants, located mainly beneath the canopy of adult trees. Resprouting from a root crown of a swollen root, enables the survival of small plants by the accumulation of starch and water and at the same time it provides the capacity of sprouting from underground protected buds (González 1967, Oliveira \& Silva 1993). Coutinho (1982) in Brazil, as well as Cesar \& Menaut (1974) in the Ivory Coast, noticed that not only do adult savanna plants respond to fire damage by profuse sprouting from underground parts, but even seedlings show this capacity of sprouting when damaged.

It is interesting how $B$. crassifolia and $P$. rigida differ so strikingly in the germination behaviour of buried seeds. Whereas in the former, germination proceeds with an early small burst of germination, possibly followed by a second peak in the next favourable period, and little or no germination thereafter, in the latter, it occurs concurrently at the beginning of the following rainy season, 1 y after dispersal. Since half the seeds of $P$. rigida remain viable for a year, there must be an innate dormancy mechanism in these species, which would explain the failure to germinate under any treatment in laboratory experiments. In $B$. crassifolia there seems to be a quiescence mechanism imposed by the seed's very hard coat. This is supported by the laboratory germination experiments, showing that the seed coat is very difficult to break and only mechanical cracking succeeded to obtain germination. There is no dormancy 
in $B$. virgilioides and in the field, seeds should germinate as soon as the rains start.

Under laboratory conditions the seeds of $B$. crassifolia and $P$. rigida were not able to survive $92{ }^{\circ} \mathrm{C}$ of wet heat or $100^{\circ} \mathrm{C}$ of dry heat for time periods greater than 1 min. Savanna fires may affect survival of these seeds on the surface or buried shallow in the soil, depending on fire intensity and speed. Silva et al. (1990) reported temperatures over $100{ }^{\circ} \mathrm{C}$ at $5 \mathrm{~mm}$ below ground in Barinas (Venezuela), Vareschi (1962) measured $90{ }^{\circ} \mathrm{C}$ for $5 \mathrm{~min}$ in Calabozo (Venezuela), and Coutinho (1982) reports a maximum of $74^{\circ} \mathrm{C}$ at soil surface in Brazil. B. virgilioides seeds have been reported surviving temperatures of $90{ }^{\circ} \mathrm{C}$ for $5 \mathrm{~min}$ but not to $150{ }^{\circ} \mathrm{C}$ for 5 min (González 1967). However, seeds may escape fire hazards by being buried deeper in the soil.

In a seasonal environment like the savanna, there is a selective advantage in germinating at the beginning of the favourable period, since the seedlings are maximizing the length of the first growth period before the unfavourable season starts. If the seeds are dispersed later in the season, postponing germination until the following season (as P. rigida does) would then be advantageous. Savanna grass species blooming after May and lacking a permanent seed bank exhibit this germination pattern (Silva \& Ataroff 1985). The same results would be achieved by $B$. virgilioides by other means, rapid dispersal before the dry season is over and quick massive germination as soon as the soil gets wet. For several cerrado woody species, Oliveira (1998) showed that those seeds dispersed by wind do not present dormancy, hence germination proceeds immediately after dispersal, as soon as the rains start. On the other hand, those dispersed by animals, have dormancy mechanisms that delay the germination process until favourable conditions are present. However, both strategies converge in order to synchronize the germination and establishment events in the beginning of the favourable period.

In general, our results indicate that even though a high fire frequency prevails in this savanna, the studied species produce a sizable number of viable propagules, and have the capacity to germinate in field conditions (readiness depending on the species). Therefore, we expect sexual reproduction to play an important role, as suggested by their reproductive investment, in long-term population maintenance. Although annual seedling recruitment in these populations seems to be rather low, this process may be increased during favourable episodes such as the occurrence of wetter years (Medina \& Silva 1990).

\section{AGKNOWLEDGEMENTS}

This work was supported by the CDCHT-ULA grant number C-591-93A to AA and JFS. Also, CGN acknowledges support through a PIN fellowship from CONICIT-ULA. We thank F. Rada for valuable suggestions and corrections to the manuscript, E. Pucheta (RLB fellowship) for his collaboration in early stages of this study and Don Luis Nieto for field and laboratory assistance. 


\section{LITERATURE CITED}

BAWA, K. S. 1974. Breeding systems of tree species of a lowland tropical community. Evolution 28:85-92.

BRADSTOCK, R. A. \& MYERSCOUGH, P. J. 1988. The survival and population response to frequent fires of two woody resprouters Banksia serrata and Isopogon anemonifolius. Australian Journal of Botany 36:415-431.

CESAR, J. \& MENAUT, J. C. 1974. Le pleuplement vegétale. Bulletin de Liaison des Chercheurs de Lamto, Numéro special 2:1-16.

COUTINHO, L. M. 1982. Ecological effects of fire in Brazilian Cerrado. Pp. 273-292 in Huntley, B. J . \& Walker, B. H. (eds). Ecology of tropical savannas. Ecological Studies 42, Springer-Verlag, Berlin.

FARJI-BRENNER, A. \& SILVA, J. F. 1995. Leaf-cutting ants and forest groves in tropical savanna: facilitated succession? Journal of Tropical Ecology 11:651-669.

FERRI, M. G. 1961. Aspects of the soil-water relationships in connection with some Brazilian types of vegetation. Tropical Soils and Vegetation. Proceedings of the Abidjan Symposium, pp. 103-109. UNESCO.

GONZÁLEZ, V. C. 1967. Efectos del fuego sobre la reproducción de algunas plantas de los llanos de Venezuela. Boletin de la Sociedad Venezolana de Ciencias Naturales 111:70-103.

HOFFMANN, W. A. 1996. The effects of fire and cover on seedling establishment in a neotropical savanna. Journal of Ecology 84:383-393.

HOFFMANN, W. A. 1998. Post-burn reproduction of woody plants in a neotropical savanna: the relative importance of sexual and vegetative reproduction. Journal of Applied Ecology 35:422-433.

KEELEY, J. E. 1977. Seed production, seed population in soil, and seedling production after fire for two congeneric pairs of sprouting and nonsprouting chaparral shrubs. Ecology 58:820-829.

KEELEY, J. E. 1987. Role of fire in seed germination of woody taxa in California chaparral. Ecology 68:434-443.

LABOURIAU, L. G., VALIO, I. M. \& HERINGER, E. P. 1964. Sobre os sistemas reprodutivos de plantas dos cerrados. Anais da Academia Brasileira de Ciencias 36:449-464.

MEDINA, E. \& SILVA, J. F. 1990. The savannas of northern South America: a steady state regulated by water-fire interactions on a background of low nutrients availability. Journal of Biogeography 17:403413.

MOORE, R. P. 1973. Tetrazolium staining for assessing seed quality. Pp. 347-366 in Heydecker, W. (ed.). Seed ecology. Butterworths, London.

OLIVEIRA, P. E. \& SILVA, J. C. S. 1993. Reproductive biology of two species of Kielmeyera (Guttiferae) in the cerrados of Central Brazil. Journal of Tropical Ecology 9:67-79.

OLIVEIRA, P. E. 1998. Fenologia e biologia reproductiva das especies de Cerrado. Pp. 169-192 in Sano, S. M. \& Pedrosa de Almeida, S. (eds). CERRADO: ambiente e flora. EMBRAPA, Planaltina, DF.

PIERCE, S. M. \& COWLING, R. M. 1991. Dynamics of soil-stored seed banks of six shrubs in fire-prone dune fynbos. Journal of Ecology 79:731-747.

RAMÍREZ, N. 1993. Producción y costo de frutos y semillas entre formas de vida. Biotropica 25:46-60.

RIZZINI, G. T. \& HERINGER, E. P. 1962. Studies on the underground organs of trees and shrubs from some southern Brazilian savannas. Anais da Academia Brasileira de Ciências 34:235-247.

SARMIENTO, G. 1984. The ecology of neotropical savannas. Harvard University Press, Cambridge, MA.

SILVA, J. F., \& ATAROFF, M. 1985. Phenology, seed crop and germination of coexisting grass species from a tropical savanna in western Venezuela. Acta Oecologica, Oecologia Plantarum 6:41-51.

SILVA, J. F. \& SARMIENTO, G. 1976. La composición de las sabanas en Barinas en relación con las unidades edáficas. Acta Cientifica Venezolana 27:68-78.

SILVA, J. F., RAVENTÓS, J. \& CASWELL, H. 1990. Fire, fire exclusion and seasonal effects on the growth and survival of two savanna grasses. Acta Oecologica 11:783-800.

SOLBRIG, O. T., MEDINA, E. \& SILVA, J. F. 1996. Determinants of tropical savannas. Pp. 31-44 in Solbrig, O. T., Medina, E. \& Silva, J. F. (eds). Biodiversity and savanna ecosystem processes. Ecological Studies 121, Springer-Verlag, Berlin.

THOMPSON, K. 1993. Persistence in soil. Pp. 199-202 in Hendry, G. A. F. \& Grime, J. P. (eds). Methods in comparative plant ecology, a laboratory manual. Chapman \& Hall, London.

VARESCHI, V. 1962. La quema como factor ecológico de los llanos. Boletin de la Sociedad. Venezolana de Ciencias Naturales 101:9-31.

WÜTHERICH, D., AZÓCAR, A., GARCÍA-NÚÑ̃Z, C. \& SILVA J. F. in press. Seed dispersal in Palicourea rigida, a common treelet species from neotropical savannas. Journal of Tropical Ecology 17:449_ 458.

ZAMMIT, C. A. \& ZEDLER, P. H. 1992. Size structure and seed production in even-aged populations of Ceanothus greggii in mixed chaparral. Journal of Ecology 81:499-511. 